Boise State University

ScholarWorks

$10-1-2016$

\title{
Promoting Financial Capability of Incarcerated Women for Community Reentry: A Call to Social Workers
}

Cynthia K. Sanders

Boise State University 


\title{
Promoting Financial Capability of Incarcerated Women for Community Reentry: A Call to Social Workers
}

\author{
Cynthia K. Sanders \\ Boise State University
}

\begin{abstract}
Female incarceration rates are increasing at unprecedented rates. The majority of women are poor single mothers, serving sentences for nonviolent drug-related and property offenses. Among challenges faced when transitioning back into society are a history of interpersonal violence and financial instability. This study examines literature with regard to the barriers women experience with an emphasis on financial struggles and explores outcomes of one initiative to begin addressing the financial capability of women in a minimum security prison. Findings reveal women benefited from the class experience. Social workers are called upon for additional financial capability programming and research in this area.
\end{abstract}

Female incarceration rates are increasing at an unprecedented rate. In recent decades, the increase in the female prison population has continuously surpassed that of the male prison population, making women the fastest growing segment of the U.S. prison population (Allen, Flaherty \& Ely, 2010, p. 160; Greene, Pranis, \& Frost, 2006; Mallicoat, 2012, Section X, p. 491). Between 1980 and 2010, the number of women in prison increased by 646 percent. There are over 200,000 incarcerated women constituting nearly $10 \%$ of the total U.S. prison and jail population. Additionally, there are over one million women on probation or parole (ACLU, 2009; The Sentencing Project, 2012).

"Women in prison are among the most vulnerable and marginalized members of society" (Women in Prison Project, 2006, p. 4). The majority of women involved in the criminal justice system are poor single mothers, most of whom are serving sentences for nonviolent drug-related and property offenses (Moe \& Ferraro, 2006; Mallicoat, 2012, Section X, p. 492). Black women imprisonment rates are nearly three times that of white non-Hispanic females (Guerino, Harrison, \& Sabol, 2012). The erosion of social service benefits in the welfare state alongside the passage of draconian laws against drug use has resulted in America's war on drugs sometimes being referred to as a war on poor and minority women (Bush-Baskette, 2000; Van Wormer, 2008). Over 95\% of state prisoners will be released at some point back into society (Hughes \& Wilson, 2015). While gender-responsive programing has received more attention in recent years, practices in correctional settings are still largely developed for and by males, and females are often an afterthought in terms of incarceration planning and planning for reentry (Mallicoat, 2012, pp 1-12; Thompson 2010). Genderresponsive approaches for women could focus on a variety of issues, including the fact that women are more likely than men to be the custodians of their children (Allen, Flaherty \& Ely, 2010), and high documented rates of domestic violence among incarcerated women (Zust, 2008). While this paper focuses on a gender- specific initiative as it pertains to domestic violence, financial education, and empowerment, this paper does not intend to diminish the need for genderresponsive programs and prison reform for men as well.

Women face many challenges when transitioning back into society. The magnitude of policy and institutional change that is needed to address these challenges is beyond the scope of this paper. However, one key challenge women face when reentering communities is financial stability (O'Brien \& Lee, 2006). Financial issues are frequently reported as a major concern among inmates and frequently a factor in why women offend in the first place (Johnson, 2014). In the context of multiple oppressions women's financial knowledge and access to financial resources is severely limited. Additionally, given the alarming rates of a history of domestic violence, women may find themselves isolated from financial information and resources, and prone to economic reliance on an abusive partner (Sanders, 2014; Zust, 2008). Promoting financial capability which involves both financial knowledge and access to financial resources (Birkenmaier, Sherraden, \& Curley, 2013) may provide one tool for increasing women's economic stability upon reentry by improving women's ability to recognize economic abuse, independently manage finances, learn skills to cope with financial problems, and differentiate between reputable financial services and predatory lenders (Postmus, Plummer, McMahon, \& Zurlo, 2012; Sanders, 2013). Financial management skills are essential in daily life, from running a household to making ends meet. In addition, providing financial education skills are associated with psychosocial wellbeing including, economic empowerment and financial self- efficacy among women (Postmus, Plummer, McMahon, \& Zurlo, 2012; Sanders, Weaver, \& Schnabel, 2007). Advancing women's financial literacy may be especially important 
This is an author-produced, peer-reviewed version of this article. The final, definitive version of this document can be found online at Journal of Community Practice, published by Routledge. Copyright restrictions may apply. doi: 10.1080/10705422.2016.1233161

since in general women consistently demonstrate lower financial literacy than men (Bucher-Koenen, Lusardi, Alessie, \& van Rooij, 2014). In this study the term financial literacy refers to skills and knowledge that allow individuals to make informed and effective decisions given their financial resources. It also includes a dimension of financial empowerment and financial self-efficacy which reflects a person's sense of hope and confidence in meeting financial goals (Weaver, Sanders, Schnabel, \& Campbell, 2009). The key distinction between financial literacy and financial capability is that to be financially capable, people must be more than financially literate they must also have access to financial products and services (Birkenmaier, Sherraden, \& Curley, 2013, p. 3). Financial literacy might be viewed as a step toward building financial capability but not sufficient to do so.

This study examines current literature with regard to the barriers women experience when reentering society following incarceration with an emphasis on economic struggles. Additionally, this study examines the outcomes of a financial education and empowerment program developed with the needs of woman survivors of intimate partner violence (IPV) in mind that was delivered in a minimum security women's correctional facility $(n=288)$.

\section{Review of the Literature}

\section{Barriers to reentry}

"Women inmates represent a myriad of voices that speak to poverty-stricken lives, histories of abuse, separations of mothers and children, struggles with substance abuse, problematic family relationships, health issues, and economic hardships" (Johnson, 2014, p. 365). Among the most difficult barriers women face in the reentry process are economic in nature including limited education, social capital, or marketable skills (Travis \& Stacey, 2010). Additionally access to social welfare programs, to which women may initially turn for economic support, are restricted due to drug-related crimes (Johnson, 2014; Allard, 2002). For example, unless they opt out, all states deny federal benefits such as SNAP and TANF to people convicted in state or federal courts of felony drug offenses. The ban is imposed for no other offenses but drug crimes (Mauer \& McCalmont, 2013, p. 1). Social and human capital deficiencies, along with the all too often disenfranchised community context to which women return, paints a picture in which the odds seem stacked against women for successful reintegration.

Literature consistently documents the difficult histories of incarcerated women (Allen, Flaherty, \& Ely, 2010). Themes that continuously emerge include poverty, abuse, mental health problems, and victimization. Prior to incarceration, women are more likely to live in poverty, less likely to have been employed, and more likely to have lower educational levels and lower household incomes than their incarcerated male counterparts (Mallicoat, 2012, Section X, p. 493; Moe \& Ferraro, 2006). These factors, among others, present significant barriers to successful community rentry and are factors in recidivism among women (Alleyne, 2006). According to an analysis of recidivism data from 15 states, 58\% of women released from state prison in 1994 were rearrested, 38\% were reconvicted, and 30\% returned to prison within three years (Deschenes, Owen, \& Crow, 2007, p. 22). It is noteworthy that more current statistics on recidivism rates by gender are not available.

\section{$\underline{\text { History of violence }}$}

Incarcerated women are at higher risk of various forms of violence historically and may continue to experience physical, psychological, or sexual abuse while they are incarcerated (Kim, 2003). One of the most widely prevalent characteristics among incarcerated women is the extremely high rate of historical physical and sexual abuse - as much as $80 \%$ and at least $50 \%$ of female inmates report having been abused by intimate partners (Harrison \& Beck, 2006). Additionally, a history of exchanging sex for drugs or money for many incarcerated women demonstrates how female inmates may lose control over their lives through domestic violence, street violence, and disempowering life circumstances (Sherman et al., 2006). Finally, it is important to acknowledge the role of economic abuse in domestic violence. Evidence indicates abusive partners often engage in economic abuse and use a variety of tactics that negatively impact women financially (Postmus, Plummer, McMahon, Murshid, \& Kim, 2012; Sanders, 2014a). Based on in-depth qualitative interviews with women survivors, Sanders (2014a) reports that among other things abusive partners may completely control household financial resources, monitor spending, use money for sexual exploitation, leave women's names off of bank accounts, and intentionally cause credit problems. This may leave women isolated from financial information and "unbanked." To meet their basic needs as well as those of children, women may become economically dependent on abusive partners. Additionally, abusive partners often engage in behaviors that restrict a woman's ability to pursue education, or gain and maintain employment which might result in greater financial autonomy (Sanders, 2014). 
Research also demonstrates that even while incarcerated women may continue to experience abuse from intimate partners. Women may continue to be controlled, manipulated, threatened, and even stalked by their abusers. Examples of tactics include refusing to bring children for visits; thus maintaining isolation, interfering with access to legal assistance, and threatening family members (Richie, 2001). Thus, women often experience abuse prior to incarceration, continue to be vulnerable to abuse while incarcerated, and frequently return to abusive relationships and high risk environments following incarceration.

Financial capability initiatives and research are lacking with women in prison who may be survivors of domestic violence. However, research on financial literacy and capability initatives with survivors of domestic violence outside of the prison context have reported positive and promising outcomes. For example, a controlled study that examined the Allstate Foundation financial education curriculum, by Postmus, Hetling, and Hoge (2015) reported treatment group outcomes of greater financial knowledge, financial intentions and behaviors, and a decrease in financial strain.

A financial capability initiative using the REAP curriculum paired with an individual development account (matched savings) program provided women an opportunity to apply financial knowledge to savings behavior and access to a bank account. Among 125 women, approximately two-thirds reached their savings goal and $76 \%$ made a least one matched savings withdrawal. On average women saved $\$ 1,045$ and received a two to one match resulting in average savings accumulation of $\$ 3,041$. Matched withdrawals were used to facilitate asset development including postsecondary education, small business development, or purchase of a reliable vehicle. Additionally, a few unique accounts were used for safety planning; which may for example enable a woman to move to a different state, or secure independent housing (Sanders, 2014b).

\section{Economic barriers and financial literacy}

Among the most cited economic barriers for women transitioning back into society are employment, safe, decent, and affordable housing, reliable transportation, monthly fees such as monthly parole supervision fees or restitution, and an inability to pay basic monthly expenses such as rent, utilities, food, clothing, health care, and child care costs (Johnson, 2014; O'Brien, 2001; O’Brien \& Lee, 2006). According to a study by Johnson (2014), the immediate financial goal among women on parole was to have a job with enough salary to pay basic needs and a limited amount of money for unexpected situations (p. 383). While correctional facilities may provide reintegration programing on a variety of topics including life skills, jobs skills, parenting skills, substance abuse treatment, coping skills and others, one area that appears lacking is in financial literacy (Poby, 2009). Additionally, gender-specific and gender-sensitive programs are lacking. Using male programming may reinforce power inequalities and gender stereotypes (Bloom, Owen, Covington, \& Raeder, 2002). The United States Department of Justice National Institute of Corrections recognizes that women have unique and diverse sets of risks and needs based on lived experiences which should be addressed through women centered programing (Bloom, Owen, Covington, \& Reader, 2005).

According to Bloom and Covington (2000) "Gender-responsive means creating an environment through site selection, staff selection, program development, content, and material that reflects an understanding of the realities of women's lives and addresses the issues of the participants. Gender-responsive approaches are multidimensional and are based on theoretical perspectives that acknowledge women's pathways into the criminal justice system. These approaches address social (e.g., poverty, race, class, and gender inequality) and cultural factors, as well as therapeutic interventions. These interventions address issues such as abuse, violence, family relationships, substance abuse, and co-occurring disorders. They provide a strength-based approach to treatment and skill building. The emphasis is on self-efficacy" (Bloom, Owen, Covington, \& Reader, 2005, p. 2).

Financial knowledge and skills are important daily living tools that may help support household and family financial stability, and in some cases may even help prevent criminal behavior. Because many of the crimes women commit are money related (drug offenses, property violations, prostitution etc.) finding ways to empower women economically and increase their financial capability may help reduce risk of recidivism and improve economic well-being. Providing financial literacy programing to incarcerated women is an opportunity to reach a very vulnerable population that may otherwise be missed through other systems (Alemagno \& Dickie, 2005).

Research on financial literacy with prison populations is very limited to date. Two studies (Call, 2011; Koenig, 2007) have examined the level of financial literacy among male inmates. Poby (2009) developed a financial education program for incarcerated women but does not appear to have tested the effects. Additional initiatives may be underway 
This is an author-produced, peer-reviewed version of this article. The final, definitive version of this document can be found online at Journal of Community Practice, published by Routledge. Copyright restrictions may apply. doi: 10.1080/10705422.2016.1233161

such as teaching the FDIC Money Smart Program in prison (ourprisonneighbors.org). However, this initiative appears to be gender neutral and thus does not take into account unique circumstances women may face including domestic violence.

This study examines whether or not the provision of a financial education curriculum designed with the unique needs of women survivors in mind results in increased financial literacy. Implications include the need to move beyond financial literacy to advancing the financial capability of women reentering communities following incarceration.

\section{Methodology}

\section{Participants}

Women who are part of this study $(\mathrm{N}=288)$ were incarcerated at the South Boise Women's Correctional Center (SBWCC) and participated in the Treasure Valley Economic Action Program (TVEAP). They voluntarily participated in the TVEAP program between July, 2012 and October, 2014. SBCC is a transition and treatment facility for minimum security female offenders. SBWCC provides various "rider" programs including the Correctional Alternative Placement Program (CAPP), Traditional Rider, and Therapeutic Community. Additionally, residents may be at SBWCC in the work opportunity program, be probation violators who have returned to serve a term, or be "termers" who have been sentenced to a term of incarceration of over one year (https://www.idoc.idaho.gov/content/prisons).

Rider programs are a sort of middle ground between going to prison and being placed on felony probation. Essentially, a defendant is given a prison sentence but placed in a Rider program instead. If the defendant successfully completes the program within 365 days they may be placed on probation rather than completing a prison term. The CAPP rider program includes a 90 day substance abuse treatment program, traditional rider program is focused on cognitive and behavioral change and is generally 5-6 months; and a Therapeutic Community Rider is more intensive and typically lasts between 9-12 months and also typically involves substance abuse treatment (http://atkinsonlawoffices.com/blog/rider/). Almost half of the women in this study $(49 \%, \mathrm{n}=140)$ were in the CAPP or therapeutic community rider program (a limitation of the data is there is no distinction between women in one or the other), 35\% ( $\mathrm{n}=100)$ were in a traditional rider program; 9\% $(\mathrm{n}=25)$ were in the work center; $8 \%(\mathrm{n}=22)$ were "termers" and one participant was serving a term due to probation violation. TVEAP is a community based economic education initiative aimed toward survivors of intimate partner violence (IPV) and takes place the Boise, Idaho region. The curriculum is delivered in several locations throughout the treasure valley by instructors employed through the Women and Children's Alliance (WCA), a domestic violence service provider whose vision is "to foster a community where individuals thrive in safe, healthy relationships" (http://www.wcaboise.org). The Women and Children's Alliance was approached by the Idaho Department of Corrections and asked to deliver the curriculum within the South Boise Women's Correctional Center, indicating their understanding that many of their residents had histories of intimate partner violence.

TVEAP utilizes Redevelopment Opportunities for Women's Economic Action Program (REAP) 12 hour financial education and credit counseling program (Sanders, Weaver \& Schnabel, 2007; ROW, 2005). The REAP curriculum is a financial education program developed with the unique needs of women survivors in mind (Sanders, Weaver, \& Schnabel, 2007) and underscores safety issues as a central component; including discussion of economic abuse in intimate partner relationships, short and long-term financial goals, and focuses on not only strategies that address basic financial skills, but also approaches that empower women and give them a sense of hope about their financial future (Sanders \& Schnabel, 2006). As warranted the instructors adjusted the curriculum to be relevant to the circumstances of women currently incarcerated with an emphasis on the applicability of content as women transition back into society. Although women were incarcerated, they voluntarily participated in the TVEAP classes.

\section{REAPCurriculum}

The REAP curriculum was developed through a collaborative of 13 domestic violence service agencies and three homeless agencies in the St. Louis, Missouri region (Sanders \& Schnabel, 2006). The curriculum is made up of four courses that build on each other, although each class can also stand alone. To begin, each woman is given an economic action plan (EAP) they will work on over the course of four class sessions. The EAP guides women as they create financial goals and learn to view themselves as competent financial actors. Safety is an important part of the curriculum, which recognizes that safety considerations may force women to deviate from financial goals when IPV is present. For the incarcerated women in this study, these concepts are placed in the context of their previous life experiences as well as thinking about how safety and healthy relationships are important as they transition back into society. 
Section one emphasizes economic empowerment. Women explore their feelings about money and begin to examine the factors that have shaped their financial situation. Many women who have experienced intimate partner violence and economic abuse have had limited opportunities to discuss their feelings about money, or the role that financial matters may have played in experiences of IPV (Sanders, 2014; Weaver, Sanders, Schnabel \& Campbell, (2009). Section two helps women develop a budget (cost of living plan) that would meet their more immediate needs as well as enables them to begin to think about ways to accomplish long-term economic goals. The importance of organizing financial and personal documents, learning about budgets and financial terms, and identifying "spending leaks" are emphasized. Safety considerations include acknowledging that women may be limited to making only small financial decisions and goals, especially at first, because they may lack control over household expenses and spending.

Section three focuses on understanding credit and debt. Women learn about their credit report. They are given specific steps that will help improve their credit and achieve personal goals. Examples of safety considerations include making sure a credit report can be mailed to a safe address and whether an abuser can access her credit report (using a social security number) and learn where she is living. In such cases the class facilitator brainstorms with participants how they might go about getting their credit report safely.

Section four examines financial products and services, savings, and investments, as well as potentially predatory alternative financial services. While bank accounts may be financially optimal for many women, some women are not comfortable opening a bank account for a variety of reasons such as safety, credit history, or discrimination. Additionally, for women with criminal records gaining access to financial institutional structures may be even more complicated. Safety considerations may include opening new financial accounts at a financial institution other than that of an abusive partner, and using an employment address or post office box for financial mailings.

As a whole the REAP curriculum promotes women's empowerment and financial self-determination, provides hands-on skills, and aims to increase knowledge of and access to financial resources, increase women's self-confidence in managing and coping with financial issues, and assist women in identifying feasible short- and long-term financial goals through an individualized economic action plan (EAP). REAP was designed with the needs of survivors of IPV in mind (which a large proportion of incarcerated women are) but not with the needs of incarcerated women specifically in mind. Thus, as noted early, instructors adjust the curriculum as they deem relevant to the circumstances of women currently incarcerated with an emphasis on the applicability of content as women transition back into society. Nonetheless, this is also a limitation of the program. However, providing women with tools to take positive financial steps upon community reentry is viewed as positive measure.

\section{$\underline{\text { Data }}$}

Data for this study were acquired by the researcher as secondary data from the Women and Children's Alliance with identifying information removed. Data were entered into SPSS for data analysis. Participants of TVEAP were asked by course instructors to complete a series of forms, including pre/post quizzes for each of the four classes offered, and a written informed consent. Course instructors explained the program and informed women that by filling out the forms they were agreeing to allow use of the data for program evaluation and research purposes.

\section{$\underline{\text { Instruments }}$}

Several data collection instruments are routinely used by the Women and Children's Alliance in delivery of the TVEAP program. These include a participant enrollment and consent to participate form; a demographic information survey; an economic abuse checklist; and pre and post quizzes for each of the four modules of the 12 hour economic education curriculum.

The economic abuse checklist was developed by the author at the request of the Women and Children's Alliance when TVEAP was initiated in the Boise, Idaho region. They utilize this checklist in their intake process with shelter clients and collect this information at all of their TVEAP classes. Their purpose is to document the degree to which their target population experiences the economic abuse dimension of IPV. The author developed the checklist based on research about economic abuse and tactics of abusive partners (Adams, Sullivan, Bybee \& Greeson, 2008; Weaver, Sanders, Schnabel \& Campbell, 2009). It includes 20 item indicators of the presence or absence of economic abuse. Women answer each question in nominal terms of yes or no as it relates to their most recent relationship. 
This is an author-produced, peer-reviewed version of this article. The final, definitive version of this document can be found online at Journal of Community Practice, published by Routledge. Copyright restrictions may apply. doi: 10.1080/10705422.2016.1233161

For each of the four classes a simple quiz is used to assess whether or not participants are acquiring basic knowledge. The four quizzes were created collaboratively with staff from the Women and Children's Alliance when they began to deliver the curriculum in the Boise, Idaho area. They are designed to assess basic content in each of the four class areas including, economic empowerment, credit and debt, budgets and costs of living, and financial products and services. Questions are true/false, multiple choice, and fill in the blank in nature. Questions assess both factual knowledge about financial planning and credit repair (e.g. a credit card is an example of what type of credit?; name the three credit bureaus; true or false a safety deposit box is the best place to keep the only copy of your will?) as well as understanding and attitudinal outcomes related to economic abuse and empowerment (e.g name the four types of abuse; increasing your ability to make positive choices about your own destiny' is the definition of?) Based on the number of questions, quiz one is worth 10 points, quiz two 7 points, quiz three 7 points, and quiz four 5 points. Taken together a combined score for all four classes could range from 0-29 points. Methods for acquiring, analyzing, and reporting data for this study were approved through a university institutional review board.

\section{$\underline{\text { Data Analysis }}$}

Data were analyzed using SPSS. Descriptive analyses are conducted to examine the characteristics of 288 incarcerated women who voluntarily participated in the TVEAP program between July, 2012 and October, 2014; economic abuse checklist to monitor whether and to what extent women have experienced economic abuse in their most recent intimate relationship; and pre and post quiz scores for each of the four classes as well as total combined score. Paired sample ttests were used to examine whether pre and post quiz scores change significantly. Analysis of variance was used to examine whether outcomes differed by program status (traditional rider, therapeutic community etc.) Not all 288 women completed all four sections and/or both pre and post quizzes. Thus, data is shown for those who completed both pre and post measures for each quiz and for those who completed pre/post measures for all four classes combined. This ranged from all 287 women completing pre and post measures on quiz number one to only 270 women completing all four pre/post measures for analysis of total combined score outcomes (see Table 3).

\section{Findings}

\section{Women's Characteristics}

Table 1 provides basic demographic information about the women in this study. Women ranged in age from 20 to 62 with an average age of 34 years. The majority of women were white (78\%). While this is consistent with a majority Caucasian population of Idaho, it is not congruent with the over-representation of Hispanics and African Americans in Idaho prisons. Based on 2006 census data, the Hispanic population in Idaho was 9.1\%, while the Hispanic prison population was $15.8 \%$. Additionally, the African American population in Idaho was $0.6 \%$, while the African American prison population in Idaho was $2.1 \%$ (http://www.safetyandjustice.org/node/1537/). This difference could imply that either Hispanic and African American women chose not to participate in the TVEAP program, or they may have been less likely to be residents of the minimum security program.

Generally, women had minimal education with over half of women (53\%) with a high school degree or less and less than $10 \%$ of women had completed a two-year degree or more. Almost three quarters of women had children age 18 or younger.

\section{$\underline{\text { Economic Abuse }}$}

To examine the extent to which economic abuse was relevant to lives of women participating in the TVEAP program while incarcerated, they completed an "economic abuse checklist" which included 20 questions about economic abuse indicating whether or not a woman's most recent partner engaged in such tactics (Table 2). The number of indicators women reported experiencing ranged from zero $(n=20,7 \%)$ to 18 with an average of 10 . All but 20 women reported experiencing at least one indicator of economic abuse. Fifty percent of women reported experiencing between nine and 18 indicators. These data demonstrate that the majority of women had experienced some degree of economic abuse in their most recent relationship suggesting the REAP curriculum which emphasizes safety and financial matters as they relate to survivors of IPV is highly relevant. 
This is an author-produced, peer-reviewed version of this article. The final, definitive version of this document can be found online at Journal of Community Practice, published by Routledge. Copyright restrictions may apply. doi: 10.1080/10705422.2016.1233161

\section{Financial Literacy}

TVEAP offers four financial education classes based on the REAP curriculum. Data were gathered from 288 women although not all women completed pre and post-tests for all four courses. Table 3 presents pre and post quiz scores for each of the four sections as well as total score and change scores among women completing all four classes. A series of paired sample t-tests were performed to assess whether post-test scores were significantly higher than pre-test scores. Quizzes one through four, as well as total scores, were tested. Significant improvement in the number of questions answered correctly occurred in quiz one $(\mathrm{t}=-27.54, \mathrm{p} \leq .001)$; quiz $2(\mathrm{t}=-15.65, \mathrm{p} \leq .001)$; quiz $3(\mathrm{t}=-28.34, \mathrm{p} \leq .001)$; quiz $4(\mathrm{t}=-25.95, \mathrm{p} \leq \mathrm{001})$; and total score $(\mathrm{t}=-43.21, \mathrm{p} \leq .001)$. Additionally, all pre/post test scores were examined in subgroups based on program status (excluding the one participant who was serving a term due to cell size) using analysis of variance (ANOVA). No significant differences between groups were found based on F-scores and p-values all greater than .05 .

Among women completing all four pre/posttest measures $(\mathrm{N}=270)$, the average pretest score averaged 17 and improved to 26 points at posttest. This represents a nine point gain or $30 \%$ improvement on average. All t-tests were statistically significant ( $\mathrm{p} \leq .001)$ providing evidence that on average women made significant gains in their financial knowledge.

\section{Discussion}

Findings from this study demonstrate that the Treasure Valley Economic Action Program is serving survivors of domestic violence who are economically disadvantaged, experience economic abuse, and show significant increases in their financial literacy following completion of the REAP curriculum. Findings reveal that women benefit from the class experience and information provided but call for additional financial capability programing with incarcerated women who will transition back into society and evaluation measures. That is, while women had positive financial literacy outcomes, promoting financial capability will also require greater efforts to connect women to financial resources, services, and asset building initiatives as they reenter society in order to act on what they have learned and make progress in financial stability.

Importantly, TVEAP advances financial capability efforts through the provision of classes that are empowerment based and designed with the circumstances of women and safety issues as the central component. The results are promising but limited. This is an exploratory and descriptive study that examined the extent to which incarcerated women would increase their financial literacy through participation in an economic education class. It is worth mentioning that anecdotally the instructors of these courses have noted that the women who are incarcerated are in their estimation the most engaged (compared to other locations where they also teach classes) and overtly grateful for the opportunity to participate in discussions around financial struggles, economic abuse, and planning for the future economic well-being for themselves and their children.

While women acquired skills and knowledge to help them make healthy financial choices post-incarceration, women continue to face challenges within the broader social and institutional contexts of life once released. This frequently includes poverty and survival in disenfranchised neighborhoods. Women are simultaneously attempting to identify housing, a job, reestablish social relationships; which may include domestic violence, frequently attempting to regain custody of children, maintain sobriety and adhere to conditions of probation or parole.

Unfortunately, most women released from jail or prison likely return to the same disenfranchised neighborhoods, difficult conditions and inadequate services and resources to assist women in the reentry process. Women continue to be challenged by unemployment, inadequate or affordable housing options, health and mental health care needs, and the need for safety from trauma and abuse (Richie, 2001). Additionally, given the high prevalence of drug- related crimes for which women are incarcerated in this country long-term substance abuse treatment and prevention are a necessity to maintain abstinence post-incarceration (Richie and Johnsen, 1996). With more adequate resources in place, women will be better positioned to use the knowledge and skills learned in an economic education program as a meaningful tool.

Neighborhood development efforts are also needed so when women are released the find communities more equipped to provide the support they need. That is, the economic conditions in their neighborhoods need to change for them to successfully reengage with community life. Greater financial capability efforts are needed once women leave prison in order for them to safely apply the knowledge and skills they gain from programs such as the one presented here (Sanders, 2013). Financial capability moves beyond financial literacy and allows people to "to understand, access, and 
This is an author-produced, peer-reviewed version of this article. The final, definitive version of this document can be found online at Journal of Community Practice, published by Routledge. Copyright restrictions may apply. doi: 10.1080/10705422.2016.1233161

act in their best financial interest" (Johnson \& Sherraden, 2007, p. 124). Financial capability requires financial literacy, but also requires access to appropriate financial products. In other words, financial capability requires both the ability to act (knowledge, skills, confidence, and motivation) and the opportunity to act (through access to beneficial financial products and institutions) (Johnson \& Sherraden, 2007, p. 136). For example, building bridges with financial institutions in order for women to begin establishing a credit record may support them in their efforts to acquire stable housing, and reliable transportation.

Feelings of hopelessness are reported to frequently characterize the experiences of women arrested in the United States (Chapman, Specht, \& Cellucci, 2005; Richie, 2001). Thus, providing women with meaningful tools is essential. The TVEAP initiative is one that aims to promote a sense of hope, orientation toward the future, and accomplishment of short-term goals and identification of longer-term goals. However, in order for these tools to take hold, structural and community barriers to economic success must also be addressed. Successful reintegration can only become a reality when women are connected to effective reentry programs that provide assistance with employment, housing, child care, transportation and basic economic needs (Johnson, 2014, p. 385).

Women also need access to anti-poverty resources such as cash assistance and food stamps as a temporary source of support. Thus, policy provisions that deny access to social welfare programs to women convicted of felony drug related acts serve only to potentially increase the chances that women will be driven back to crime related activities in order to survive (Allard, 2002). Having access to basic economic needs first is likely to position women who participate in economic education and financial capability initiatives such as TVEAP to be even more effective in making financial decisions and managing resources in order to maintain economic stability for themselves and children.

\section{$\underline{\text { Limitations and Research Implications }}$}

This study is exploratory and descriptive in nature and thus only begins to scratch the surface of understanding the benefits of financial literacy programs with incarcerated women. The study is limited to a pre/post-test design, with no further follow-up. A three month follow-up and follow-up with participants following release from the SBWCC to examine the applicability of course content upon re-entry would have strengthened the current study. The secondary data source is based on a convenience sample of women who voluntarily participated in the TVEAP program. Thus, the study cannot be generalized beyond the sample and no control group was used to assess outcomes with and without the intervention. Finally, the sample in homogeneous in nature and does not reflect the over-representation of Hispanics and African American in the Idaho prison system.

Further studies are needed including controlled studies and qualitative studies. Qualitative inquiry would help shed light on understanding how a curriculum designed with the needs of survivors in mind could be made even more applicable to the needs of incarcerated women as they transition back into communities. Additionally, studies which examine the benefits, such as economic stability and domestic violence/healthy relationships, that may be associated with increased financial literacy once women transition back into their communities are critical. Going beyond financial literacy to issues of financial capability and understanding access to institutional structures that allow women to act on what they have learned will also be important (e.g. affordable banking services, ability to build a credit record, financial autonomy etc).

The measures used in this study are also simplistic in capturing "financial literacy." The quizzes given before and after each class are very simple in nature and measure only the most basic financial knowledge. That is, they are not comprehensive in measuring all of the content of classes. It is also conceibable that administration of quizzes to participants by course instructors could bias outcome scores. However, measuring the content more comprehensively was prohibitive in this study as it would require significant time from participants to fill out a measure and thus take away from valuable class time.

\section{A Call to Social Works}

Studies suggest supportive services, such as education, substance abuse and mental health treatment, counseling, and rehabilitation programing is not routinely available to females in prison. When they do exist they are often not gendersensitive. (Mallicoat, 2012, pp 1-12; Richie, 2001). While social workers are not as prevalent in the correctional field 
This is an author-produced, peer-reviewed version of this article. The final, definitive version of this document can be found online at Journal of Community Practice, published by Routledge. Copyright restrictions may apply. doi: 10.1080/10705422.2016.1233161

as they could be (Agllias, 2004) the relevance of our interaction with women coming out of prison who in turn struggle with poverty, homelessness, child custody, substance abuse, domestic violence, HIV and other health and mental health conditions is clear (O’Brien \& Young, 2006).

Given the vulnerable status of women in prison and the intersection of correctional issues with poverty, racism, and others, it is critical that the social work profession make efforts to have greater visibility. Recent trends in social work practice and education emphasize the importance of financial capability work (Birkenmaier, Sherraden, \& Curley, 2013). Providing economic empowerment and financial capability programs that contribute to household stability and security are vital. In order to do this however social workers must be more adequately prepared to conduct effective financial assessments with clients struggling with complex financial problems and economic circumstances, and integrate financial issues into social work (Gillen and Loeffler, 2012; Loke, Watts, \& Kakoti, 2013). Curriculum content in social work education needs to be integrated into courses on practice, policy, theory, research, and applied in practicum settings in order for social workers to become competent in delivering financial capability interventions at micro, mezzo, and macro levels. Empowerment based approaches to working with vulnerable women align well with a social work orientation (Turner \& Maschi, 2015).

Empowerment and consciousness raising approaches suggest that an important influence on a person's ability to make individual change is the extent to which she has an understanding of multiple influences on her behavior (Freire, 1970; Richie, 2001, p. 385). For incarcerated women, strategies to help them develop critical insight into structural influences on personal choices, rather than self-blame or simply focusing on self-esteem, may be especially relevant (Richie, 2001). Providing financial education and importantly promoting greater financial capability structures at an institutional level may enable women to make financial decisions that provide greater options for economic success. Social workers grounded in community and social development models are well positioned to initiate and promote structural change.

\section{Conclusion}

Despite the odds being stacked against them, some women do manage to successfully negotiate the transition from prison to community (O'Brien, 2001). Let us not underestimate their strengths and capacities while simultaneously advocating for programmatic resources and structural and policy change. Research tells us that women coming out of prison require both individualistic responses to their situations as well as addressing the ongoing economic and social constraints they face (Johnson, 2014, O'Brien \& Young, 2006; Richie, 2001). This study makes a contribution by demonstrating that women in prison are receptive and in need of efforts to advance their financial capability. Social workers are called upon to engage in initiatives to advance the financial capability of incarcerated women as they transition back into families, neighborhoods, and communities.

\section{References}

Adams, A.E., Sullivan, C.M., Bybee, D., \& Greeson, M.R. (2008). Development of the Scale of Economic Abuse. Violence Against Women, 14, 563. DOI 10.1177/1077801208315529

Agllias, K. (2004). Women in corrections: A call to social work. Australian Social Work, 57(4), 331-342.

Alemagno, S., \& Dickie, J. (2005). Employment issues of women in jail. Journal of Employment Counseling, 42, 67-74

Allard, P. (2002). Life sentences: Denying welfare benefits to women convicted of drug offenses. Washington, DC: The Sentencing Project.

Allen, S., Flaherty, C., and Ely, G (2010). Throwaway moms: Maternal Incarceration and the criminalization of female poverty. Affilia: Journal of Women and Social Work, 25(2), 160-172.

Alleyne, V. (2006). Locked up means locked out: Women, addiction and incarceration. Women and Therapy 29, 181194.

American Civil Liberties Union (2009). Women and the Criminal Justice System. Retrieved December 27, 2014 from https://www.aclu.org/prisoners-rights/women-prison

Birkenmaier, J.M., Sherraden, M., \& Curley, J.C. (2013) Eds. Financial Capability and Asset Development: Research, Education, Policy, and Practice. New York: Oxford University Press.

Bloom, B., Owen, B., Covington, S. (2005). Gender-Responsive Strategies for Women Offenders: A Summary of Research, Practice, and Guiding Principles for Women Offenders. Washington DC: National Institute of Corrections, U.S. Department of Justice. Retrieved 10/31/2015 from http://static.nicic.gov/Library/020418.pdf

Bucher-Koenen T., Lusardi A., Alessie R., \& van Rooij M. (2014). How financially literate are women? An overview and new insights. Global Financial Literacy Excellence Center (GFLEC). Washington, DC: The George 
Washington University.

Bush-Baskette, S. (2000). The war on drugs and the incarceration of mothers. Journal of Drug Issues, 30, 919-928.

Call, L.L. (2011). Exploring Financial Knowledge, Behaviors, and Economic Socialization in an Incarcerated Population: A Mixed Methods Analysis. Theses and Dissertations. Paper 2641.

Chapman, A. L., Specht, M. W. and Cellucci, T. (2005), Factors Associated with Suicide Attempts in Female Inmates: The Hegemony of Hopelessness. Suicide and Life-Threat Behavior, 35: 558-569. doi: 10.1521/suli.2005.35.5.558

Deschenes, E.P., Owen, B., \& Crow J. (2007). Recidivism Among Female Prisoners: Secondary Analysis of the 1994 BJS Recidivism Data Set. Washington. DC: U.S. Department of Justice. Retrieved 07/14/2015 from www.ncjrs.gov/pdffiles1/nij/grants/216950.pdf

Freire, P. (1970). Pedagogy of the oppressed. New York: Continuum.

Gillen, Martie and Loeffler, Diane N. (2012) "Financial Literacy and Social Work Students: Knowledge is Power," Journal of Financial Therapy: Vol. 3: Iss. 2, Article 4. http://dx.doi.org/10.4148/jft.v3i2.1692

Greene, J., Pranis, K., Frost, N. (2006). The Punitiveness Report-Hard hit: The Growth in Imprisonment of Women, 1977-2004. New York: Institute on Women and Criminal Justice, Women's Prison Association. Ebook.

Guerino, P., Harrison, P.M., \& Sabol, W.J. (2012). Prisoners in 2010. U.S. Department of Justice Office of Justice Programs, Bureau of Justice Statistics.

Harrison, P. \& Beck, A. (2006). Prisoners in 2005. Bureau of Justice Statistics Bulletin, NCJ 215092. Retrieved December 27, 2014 from http://www.bjs.gov/content/pub/pdf/p05.pdf

Hughes, R. \& Wilson, D.J. (2015). Reentry trends in the United States: Inmates returning to the community after serving time in prison. Bureau of Justice Statistics: Retrieved 07/13/2015 from www.bjs.gov/content/reentry/reentry.cfm

Johnson, I.M. (2014). Economic impediments to women's success on parole: "We need someone on our side." The Prison Journal 94(3), 365-387.

Johnson, E., \& Sherraden, M.S. (2007). From financial literacy to financial capability among youth. Journal of Sociology and Social Welfare, 34(3), 119-145.

Kim, S. (2003). Incarcerated women in life context. Women's Studies International Forum, 26(1), 95-100.

Koenig, L.A. (2007). Financial literacy curriculum: The effect on offender money management skills. Journal of Correctional Education, 58(1), 43-56.

Langan, N. P., \& Pelissier, B. M. M. (2001). Gender differences among prisoners in drug treatment. Journal of Substance Abuse 13, 291-301.

Loke, V., Watts, J.L., \& Kakoti, S.A. (2013). Financial capabilities of service providers in the asset building field. In Birkenmaier, J.M., Sherraden, M., \& Curley, J.C. Eds. Financial Capability and Asset Development: Research, Education, Policy, and Practice. New York: Oxford University Press

Mallicoat, S.L. (2012). Women and Crime: A Text/Reader, Section I, Women and Crime: An Introduction. Thousand Oaks, CA: Sage.

Mauer, M. \& McCalmont, V. (2013). A lifetime of punishment: The impact of the felony drug ban on welfare benefits. The Sentencing Project: Research and Advocacy for Reform. Retrieved 07/13/2015 from http://sentencingproject.org/doc/publications/cc_A\%20Lifetime\%20of\%20Punishment.pdf

Moe, A. M., \& Ferraro, K. J. (2006). Criminalized mothers: The value and devaluation of parenthood behind bars. Women and Therapy, 29, 135-164.

O'Brien, P. (2001). Just like baking a cake: Women describe the necessary ingredients for successful reentry after incarceration. Families in Society: The Journal of Contemporary Human Services, 82(3), 287-297.

O’Brien, P. \& Lee, N. (2006). Moving from Needs to Self-Efficacy: A Holistic System for Women in Transition from Prison. Women and Therapy, 29(3/4), 261-284. 24.

O’Brien, P. \& Young, D.S. (2006). Challenges for formerly incarcerated women: A holistic approach to assessment. Families in Society: The Journal of Contemporary Social Services, 87(3), 359-366.

Poby, K.E. (2009). Women's Financial Future: A Financial Literacy Program for Incarcerated Women. Dissertation, The Chicago School of Professional Psychology.

Postmus, J.L., Hetling, A., \& Hoge, G.L. (2015). Evaluating a financial education curriculum as an intervention to improve financial behaviors and financial well-being of survivors of domestic violence: Results from a longitudinal randomized controlled study. The Journal of Consumer Affairs, 250-266. DOI: 10.111/joca.12057

Postmus, J.L., Plummer, S. B., McMahon, S., Murshid, N.S., \& Kim, M.S. (2012). Understanding economic abuse in the lives of survivors. Journal of Interpersonal Violence, 27(3), 411-430.

Postmus, J.L., Plummer, S.B., McMahon, S., \& Zurlo, K.A. (2012). Financial literacy: Building economic empowerment with survivors of violence. Journal of Family Economic Issues, 34, 275-284. 
This is an author-produced, peer-reviewed version of this article. The final, definitive version of this document can be found online at Journal of Community Practice, published by Routledge. Copyright restrictions may apply. doi: 10.1080/10705422.2016.1233161

Richie, B.E. (2001). Challenges incarcerated women face as they return to the communities: Findings from life history interviews. Crime \& Deliquency, 47, 368-389.

Richie, B.E., \& Johnsen, C. (1996). Abuse histories among newly incarcerated women in a New York City jail. Journal of the American Medical Women's Association, 51, 111-114.

Redevelopment Opportunities for Women (ROW). (2005). Realizing Your Economic Action Plan (REAP). Published curriculum. St. Louis, MO: Author. Sanders, C.K. (2014a). Economic abuse in the lives of women abused by an intimate partner:

A qualitative study. Violence Against Women, 1-27. DOI: 10.1177/1077801214564167 Sanders, C.K. (2014b). Savings for survivors: An individual development account program for survivors of intimate partner violence. Journal of Social Service Research, 4O(3), 297-312. DOI:10.1080/01488376.2014.893950

Sanders, C.K. (2013). Financial capability among survivors of domestic violence. In Birkenmaier, J.M., Sherraden, M., \& Curley, J.C. Eds. Financial Capability and Asset Development: Research, Education, Policy, and Practice. New York: Oxford University Press.

Sanders, C.K., Weaver, T.L. \& Schnabel, M. (2007). Economic education for battered women: An evaluation of outcomes. Affilia: Journal of Women and Social Work, 22(3), 240-254.

Sanders, C.K. \& Schnabel, M. (2006). Organizing for economic empowerment of battered women: Women's savings accounts. Journal of Community Practice, 14(3), 47-68.

The Sentencing Project: Research and Advocacy for Reform (2012). Fact Sheet: Incarcerated Women. Retrieved December 26, 2014 http://www.sentencingproject.org/doc/publications/cc_Incarcerated_Women_Factsheet_De2012final.pdf

Sherman, S.G., German, D., Cheng, Y., Marks, M. \& Baily-Kloche, M. (2006). The evaluation of the JEWEL project: An innovative economic enhancement and HIV prevention intervention study targeting drug using women involved in prostitution. AIDS Care, 2006, 18(1):1-11

Thompson, A. (2010). Releasing Prisoners, Redeeming Communities: Reentry, Race, and Politics. NYU Press: New York

Travis, L., \& Stacey, J. (2010). A half century of parole rules: Conditions of parole in the United States, 2008. Journal of Criminal Justice, 38, 604-608

Turner, S.G. \& Maschi, T.M. (2015). Feminist and empowerment theory and social work practice. Journal of Social Work Practice, 29(2), 151-162.

Van Wormer, K. (2008). Anti-feminist backlash and violence against women worldwide. Social Work and Society, International Online Journal 6 (2).

Weaver, Terri L., Sanders, Cynthia K., Schnabel, Meg \& Campbell, Carole L (2009).

Development and preliminary psychometric evaluation of the domestic violence-related financial issues scale. Journal of Interpersonal Violence, 24(4), 569-585.

Women in Prison Project of the Correctional Association of New York (2006). When "free" means losing your mother: The collision of child welfare and the incarceration of women in New York State. Retrieved 04/02/2015 from: http://www.correctionalassociation.org/wp- content/uploads/2012/05/When_Free_Rpt_Feb_2006.pdf

Zust, B.L. (2008). Assessing and addressing domestic violence experienced by incarcerated women. Creative Nursing, 14(2):70-2. DOI: $10.1891 / 1078-4535.14 .2 .70$ 
Table 1. Women's Demographic Characteristics $(N=288)$

\begin{tabular}{|l|l|}
\hline Characteristic & \\
\hline Race & $225(78 \%)$ \\
White & $24(8 \%)$ \\
Latina/Hispanic & $22(8 \%)$ \\
Bi-Racial & $10(4 \%)$ \\
American Indian & $3(1 \%)$ \\
Black/non-hispanic & $2(1 \%)$ \\
Asian/Pacific Islander & $2(1 \%)$ \\
Other & \\
& \\
Education & $35(12 \%)$ \\
Less than High School & $118(41 \%)$ \\
High School or GED & $74(26 \%)$ \\
Some College & $17(6 \%)$ \\
2-Year Degree & $4(2 \%)$ \\
4-Year Degree & $2(1 \%)$ \\
Attended Graduate School & $38(13 \%)$ \\
Missing & $34($ median 31, range 20-62) \\
Age (Mean) & \\
Children & $2($ median 2, range 0-8) \\
Average number & \\
Children 18 or under & $210(73 \%)$ \\
Yes & $78(27 \%)$ \\
No &
\end{tabular}


Table 2. Economic Abuse Checklist Indicators in Most Recent Relationship (N=288)

\begin{tabular}{|c|c|c|}
\hline Indicator & Yes $\%$ & No $\%$ \\
\hline Does your partner prevent you from working or attending school? & $50 \%$ & $50 \%$ \\
\hline $\begin{array}{l}\text { Does your partner interfere with work performance through harassing and } \\
\text { monitoring your activities? }\end{array}$ & $51 \%$ & $\begin{array}{l}32 \% \\
17 \% \mathrm{NA}\end{array}$ \\
\hline $\begin{array}{l}\text { Does your partner make you feel as though you don't have a right to know } \\
\text { any details about money or household resources? }\end{array}$ & $55 \%$ & $45 \%$ \\
\hline $\begin{array}{l}\text { Does your partner prevent you from having access to household money or } \\
\text { financial resources? }\end{array}$ & $62 \%$ & $38 \%$ \\
\hline Does your partner steal money from you or your family? & $50 \%$ & $50 \%$ \\
\hline Does your partner force you to give access to your accounts? & $39 \%$ & $61 \%$ \\
\hline Does your partner refuse to help support the family financially? & $46 \%$ & $54 \%$ \\
\hline Does your partner destroy your personal belongings? & $74 \%$ & $26 \%$ \\
\hline $\begin{array}{l}\text { Does your partner make financial or investment decisions that affect you } \\
\text { or your family without consulting you? }\end{array}$ & $71 \%$ & $29 \%$ \\
\hline $\begin{array}{l}\text { Does your partner overuse your credit cards or refuse to pay the bills } \\
\text { (negatively impacting your credit)? }\end{array}$ & $58 \%$ & $42 \%$ \\
\hline $\begin{array}{l}\text { Does your partner prevent you from owning or using credit cards or } \\
\text { bankcards? }\end{array}$ & $34 \%$ & $66 \%$ \\
\hline Does your partner refuse to put your name on bank accounts? & $63 \%$ & $37 \%$ \\
\hline $\begin{array}{l}\text { Does your partner refuse to put your name on other financial assets (such } \\
\text { as a home)? }\end{array}$ & $35 \%$ & $65 \%$ \\
\hline Does your partner forbid you from having a bank account? & $17 \%$ & $83 \%$ \\
\hline Does your partner use money to force you to have sex? & $19 \%$ & $81 \%$ \\
\hline Does your partner demand you hand over your paychecks? & $34 \%$ & $\begin{array}{l}51 \% \\
15 \% \text { NA }\end{array}$ \\
\hline Does your partner make you account for every penny you spend? & $54 \%$ & $46 \%$ \\
\hline $\begin{array}{l}\text { Does your partner require you to provide receipts for all your purchases } \\
\text { (for example when you go to the grocery store)? }\end{array}$ & $43 \%$ & $57 \%$ \\
\hline $\begin{array}{l}\text { Does your partner withhold physical resources including food, clothes, } \\
\text { necessary medications, or shelter for you and/or our children? }\end{array}$ & $26 \%$ & $74 \%$ \\
\hline Does your partner take your car keys to prevent you from using the car? & $65 \%$ & $35 \%$ \\
\hline
\end{tabular}




\section{Table 3. Pre and Post Quiz Scores}

\begin{tabular}{|c|c|c|c|c|c|}
\hline $\begin{array}{l}\text { Quiz } 1 \\
10 \text { Points Possible }\end{array}$ & & \multicolumn{2}{|l|}{ Questions Correct } & \multicolumn{2}{|l|}{ Percent Correct } \\
\hline Pretest score & $\begin{array}{l}(\mathrm{N}=288, \\
\text { Missing=0) }\end{array}$ & $\begin{array}{l}\text { Mean }=5.96 \\
\text { Median }=6\end{array}$ & $\begin{array}{l}\text { Range }= \\
0 \text { to } 10\end{array}$ & $\begin{array}{l}\text { Mean }=59.6 \% \\
\text { Median }=60 \%\end{array}$ & $\begin{array}{l}\text { Range }= \\
0 \% \text { to } 100 \%\end{array}$ \\
\hline Posttest score* & $\begin{array}{l}(\mathrm{N}=287, \\
\text { Missing=1) }\end{array}$ & $\begin{array}{l}\text { Mean }=8.79 \\
\text { Median }=9\end{array}$ & $\begin{array}{l}\text { Range }= \\
2 \text { to } 10\end{array}$ & $\begin{array}{l}\text { Mean }=87.9 \% \\
\text { Median }=90 \%\end{array}$ & $\begin{array}{l}\text { Range }= \\
20 \% \text { to } 100 \%\end{array}$ \\
\hline Change in \# or \% & $\begin{array}{l}(\mathrm{N}=287 \\
\text { Missing=1) }\end{array}$ & $\begin{array}{l}\text { Mean change }= \\
2.79 \\
\text { Median }=3\end{array}$ & $\begin{array}{l}\text { Range }= \\
-2 \text { to } 9\end{array}$ & $\begin{array}{l}\text { Mean change }= \\
27.9 \% \\
\text { Median }=30 \%\end{array}$ & $\begin{array}{l}\text { Range }= \\
-20 \% \text { to } 90 \%\end{array}$ \\
\hline \multicolumn{6}{|c|}{287 women completed pre and post quiz; 264 out of 287 improved $(92 \%)$} \\
\hline $\begin{array}{l}\text { Quiz 2 } \\
7 \text { Points Possible }\end{array}$ & & \multicolumn{2}{|l|}{ Questions Correct } & \multicolumn{2}{|l|}{ Percent Correct } \\
\hline Pretest score & $\begin{array}{l}(\mathrm{N}=282, \\
\text { Missing= 6) }\end{array}$ & $\begin{array}{l}\text { Mean }=5.23 \\
\text { Median }=6\end{array}$ & $\begin{array}{l}\text { Range }= \\
0 \text { to } 7\end{array}$ & $\begin{array}{l}\text { Mean }=74.7 \% \\
\text { Median }=86 \%\end{array}$ & $\begin{array}{l}\text { Range }= \\
0 \% \text { to } 100 \%\end{array}$ \\
\hline Posttest score* & $\begin{array}{l}(\mathrm{N}=283, \\
\text { Missing= 5) }\end{array}$ & $\begin{array}{l}\text { Mean }=6.47 \\
\text { Median }=7\end{array}$ & $\begin{array}{l}\text { Range= } \\
2 \text { to } 7\end{array}$ & $\begin{array}{l}\text { Mean }=92.5 \% \\
\text { Median }=100 \%\end{array}$ & $\begin{array}{l}\text { Range }= \\
29 \% \text { to } 100 \%\end{array}$ \\
\hline Change in \# or \% & $\begin{array}{l}(\mathrm{N}=282, \\
\text { Missing=6) }\end{array}$ & $\begin{array}{l}\text { Mean change }= \\
1.25 \\
\text { Median }=1\end{array}$ & $\begin{array}{l}\text { Range }= \\
-1 \text { to } 7\end{array}$ & $\begin{array}{l}\text { Mean change }= \\
18.2 \% \\
\text { Median }=14 \%\end{array}$ & $\begin{array}{l}\text { Range }= \\
-14 \% \text { to } 100 \%\end{array}$ \\
\hline \multicolumn{6}{|c|}{282 women completed pre and post quiz; 194 out of 282 improved $(69 \%)$} \\
\hline $\begin{array}{l}\text { Quiz } 3 \\
7 \text { Points Possible }\end{array}$ & & \multicolumn{2}{|l|}{ Questions Correct } & \multicolumn{2}{|l|}{ Percent Correct } \\
\hline Pretest score & $\begin{array}{l}(\mathrm{N}=277, \\
\text { Missing= 11) }\end{array}$ & $\begin{array}{l}\text { Mean }=3.45 \\
\text { Median }=3\end{array}$ & $\begin{array}{l}\text { Range }= \\
0 \text { to } 7\end{array}$ & $\begin{array}{l}\text { Mean }=49.3 \% \\
\text { Median }=43 \%\end{array}$ & $\begin{array}{l}\text { Range }= \\
0 \% \text { to } 100 \%\end{array}$ \\
\hline Posttest score* & $\begin{array}{l}(\mathrm{N}=277, \\
\text { Missing= 11) }\end{array}$ & $\begin{array}{l}\text { Mean }=6.49 \\
\text { Median }=7\end{array}$ & $\begin{array}{l}\text { Range }= \\
2 \text { to } 7\end{array}$ & $\begin{array}{l}\text { Mean }=92.8 \% \\
\text { Median }=100 \%\end{array}$ & $\begin{array}{l}\text { Range }= \\
29 \% \text { to } 100 \%\end{array}$ \\
\hline Change in \# or \% & $\begin{array}{l}(\mathrm{N}=277, \\
\text { Missing= 11) }\end{array}$ & $\begin{array}{l}\text { Mean change }=3.05 \\
\text { Median }=3\end{array}$ & $\begin{array}{l}\text { Range }= \\
-1 \text { to } 7\end{array}$ & $\begin{array}{l}\text { Mean change }= \\
43.5 \% \\
\text { Median }=43 \%\end{array}$ & $\begin{array}{l}\text { Range }= \\
-14 \% \text { to } 100 \%\end{array}$ \\
\hline \multicolumn{6}{|c|}{277 women completed pre and post quiz; 250 out of 277 improved $(90 \%)$} \\
\hline $\begin{array}{l}\text { Quiz } 4 \\
5 \text { Points Possible }\end{array}$ & & \multicolumn{2}{|l|}{ Questions Correct } & \multicolumn{2}{|l|}{ Percent Correct } \\
\hline Pretest score & $\begin{array}{l}(\mathrm{N}=272, \\
\text { Missing= 16) }\end{array}$ & $\begin{array}{l}\text { Mean }=2.74 \\
\text { Median }=3\end{array}$ & $\begin{array}{l}\text { Range }= \\
0 \text { to } 5\end{array}$ & $\begin{array}{l}\text { Mean }=54.9 \% \\
\text { Median }=60 \%\end{array}$ & $\begin{array}{l}\text { Range }= \\
0 \% \text { to } 100 \%\end{array}$ \\
\hline Posttest score* & $\begin{array}{l}(\mathrm{N}=272, \\
\text { Missing=16) }\end{array}$ & $\begin{array}{l}\text { Mean }=4.55 \\
\text { Median }=5\end{array}$ & $\begin{array}{l}\text { Range }= \\
0 \text { to } 5\end{array}$ & $\begin{array}{l}\text { Mean }=91 \% \\
\text { Median }=100 \%\end{array}$ & $\begin{array}{l}\text { Range }= \\
0 \% \text { to } 100 \%\end{array}$ \\
\hline Change in \# or \% & $\begin{array}{l}(\mathrm{N}=272, \\
\text { Missing=16) }\end{array}$ & $\begin{array}{l}\text { Mean change }=1.82 \\
\text { Median }=2\end{array}$ & $\begin{array}{l}\text { Range }= \\
-2 \text { to } 5\end{array}$ & $\begin{array}{l}\text { Mean change }= \\
36.1 \% \\
\text { Median }=40 \%\end{array}$ & $\begin{array}{l}\text { Range }= \\
-40 \% \text { to } 100 \%\end{array}$ \\
\hline \multicolumn{6}{|c|}{272 women completed pre and post quiz; 242 out of 272 improved $(89 \%)$} \\
\hline $\begin{array}{l}\text { Combined } \\
29 \text { Points Possible }\end{array}$ & & \multicolumn{2}{|l|}{ Questions Correct } & \multicolumn{2}{|l|}{ Percent Correct } \\
\hline Pretest score & $\begin{array}{l}(\mathrm{N}=270, \\
\text { Missing= 18) }\end{array}$ & $\begin{array}{l}\text { Mean }=17.35 \\
\text { Median }=17\end{array}$ & $\begin{array}{l}\text { Range }= \\
3 \text { to } 27\end{array}$ & $\begin{array}{l}\text { Mean }=60 \% \\
\text { Median }=59 \%\end{array}$ & $\begin{array}{l}\text { Range }= \\
10 \% \text { to } 93 \%\end{array}$ \\
\hline Posttest score* & $\begin{array}{l}(\mathrm{N}=270, \\
\text { Missing= 18) }\end{array}$ & $\begin{array}{l}\text { Mean }=26.29 \\
\text { Median }=27\end{array}$ & $\begin{array}{l}\text { Range }= \\
13 \text { to } 29\end{array}$ & $\begin{array}{l}\text { Mean }=90.7 \% \\
\text { Median }=93 \%\end{array}$ & $\begin{array}{l}\text { Range }= \\
45 \% \text { to } 100 \%\end{array}$ \\
\hline Change in \# or \% & $\begin{array}{l}(\mathrm{N}=270, \\
\text { Missing= 18) }\end{array}$ & $\begin{array}{l}\text { Mean }=8.92 \\
\text { Median }=9\end{array}$ & $\begin{array}{l}\text { Range }= \\
0 \text { to } 19\end{array}$ & $\begin{array}{l}\text { Mean change }= \\
30.4 \% \\
\text { Median }=31 \%\end{array}$ & $\begin{array}{l}\text { Range }= \\
0 \% \text { to } 66 \%\end{array}$ \\
\hline
\end{tabular}

*posttest score significantly higher than pretest score $\mathrm{p} \leq .05$ 